$\begin{array}{rr}\text { JURNAL } & \text { Volume } 13, \text { Nomor } 1, \text { Januari } 2017 \\ \text { FIT(1) PATOLOGI } & \text { Halaman } 1-8 \\ \text { I N D O N E I A } & \text { DOI: } 10.14692 / \text { jfi. } 13.1 .1-8\end{array}$

\title{
Deteksi Odontoglossum ringspot virus pada Anggrek Asli Koleksi Kebun Raya di Indonesia
}

\section{Detection of Odontoglossum ringspot virus on Native Orchids Collection of Botanical Gardens in Indonesia}

\author{
Mahfut $^{1}$, Budi Setiadi Daryono ${ }^{2 *}$, Susamto Somowiyarjo ${ }^{2}$ \\ ${ }^{1}$ Universitas Lampung, Lampung 35145 \\ ${ }^{2}$ Universitas Gadjah Mada, Yogyakarta 55281
}

\begin{abstract}
ABSTRAK
Anggrek asli merupakan salah satu kekayaan flora asli Indonesia yang memiliki peran penting sebagai induk persilangan dalam pemuliaan tanaman anggrek. Infeksi virus menjadi salah satu faktor pembatas dalam budi daya anggrek. Penelitian bertujuan mendeteksi dan mengidentifikasi Odontoglossum ringspot virus (ORSV) yang menginfeksi anggrek asli. Sampel dikoleksi dari tanaman bergejala asal 5 kebun raya di Indonesia, yaitu Bogor, Cibodas, Purwodadi, Balikpapan, dan Enrekang. Deteksi dan identifikasi dilakukan secara serologi menggunakan antiserum spesifik ORSV, dilanjutkan dengan metode reverse transcriptase-polymerase chain reaction (RT-PCR), dan perunutan DNA. Uji serologi menunjukkan 5 sampel bereaksi positif terhadap antiserum ORSV, yaitu pada Phalaenopsis amboinensis (KRB2) dan Phalaenopsis amabilis (KRB12) dari Kebun Raya Bogor, Phalaenopsis amabilis (KRP18) dan Dendrobium salacence (KRP20) dari Kebun Raya Purwodadi, dan Phalaenopsis modesta J. J. Sm. (KRBp5) dari Kebun Raya Balikpapan. Deteksi asam nukleat 5 sampel tersebut dengan RT-PCR menggunakan primer spesifik gen coat protein ORSV menghasilkan fragmen DNA berukuran \pm 474 pb. Analisis homologi 5 isolat ORSV tersebut menunjukkan nilai indeks similaritas (IS) sebesar $99.8 \%$ dengan 14 isolat ORSV lain. Analisis filogenetika menunjukkan isolat KRB2 dan isolat KRP18 berada dalam satu kelompok dan terpisah dengan isolat ORSV dari negara-negara lain. Ini adalah laporan pertama adanya infeksi ORSV pada anggrek asli koleksi 5 kebun raya di Indonesia.
\end{abstract}

Kata kunci: analisis filogenetika, homologi, serologi, RT-PCR

\begin{abstract}
Native orchid is one of Indonesian natural resources which play important role as parental materials in breeding program. Virus infection is one of the limiting factors in the cultivation of orchid. The purpose of this study was to detect Odontoglossum ringspot virus (ORSV) from native orchid. Symptomatic orchids were collected from 5 botanical gardens, i.e. Bogor, Cibodas, Purwodadi, Balikpapan, and Enrekang Botanical Gardens. Detection and identification was conducted by serological method using ORSV specific antisera, followed by RT-PCR and DNA sequencing. The serological test showed that 5 samples gave positive reaction against ORSV antiserum, i.e. Phalaenopsis amboinensis (KRB2) and Phalaenopsis amabilis (KRB12) from Bogor Botanical Garden, Phalaenopsis amabilis (KRP18) and Dendrobium salacence (KRP20) from Purwodadi Botanical Garden, dan Phalaenopsis modesta J. J. Sm. (KRBp5) from Balikpapan Botanical Garden. RT-PCR of the 5 samples using specific primer of ORSV coat protein gene was successfully amplified fragment DNA with size $\pm 474 \mathrm{bp}$. Homology analysis of those 5 ORSV isolates showed the highest index similiarity of $99.8 \%$ with corresponding

*Alamat penulis korespondensi: Laboratorium Genetika dan Pemuliaan, Fakultas Biologi, Universitas Gadjah Mada. Jalan Teknika Selatan, Sekip Utara, Yogyakarta 55281.

Tel: 0274-580839, Faks: 0274-580839; Surel: budi.daryono@ugm.ac.id; bs_daryono@yahoo.com
\end{abstract}


sequences from 14 other ORSV isolates. Phylogenetic analysis indicated that ORSV KRB2 and KRP18 isolates was clustered in a separate group far from ORSV isolates in other countries. This is the first report of ORSV infection on native orchids collection from 5 botanical gardens in Indonesia.

Key words: homology, phylogenetic analysis, RT-PCR, serology

\section{PENDAHULUAN}

Anggrek asli memiliki peran penting sebagai induk persilangan dalam pemuliaan tanaman yang bertujuan memperluas keragaman genetika bentuk dan warna bunga yang unik, frekuensi berbunga yang tinggi, dan tahan terhadap patogen serta cekaman lingkungan. Serangan hama penyakit menjadi salah satu kendala dalam budi daya dan pengembangan potensi anggrek. Anggrek dilaporkan dapat terinfeksi 50 jenis virus (Zettler et al. 1990; Chang et al. 2005; Navalinskiene et al. 2005). Beberapa virus yang dilaporkan menginfeksi anggrek dan memiliki penyebaran luas di Indonesia ialah Odontoglossum ringspot virus (ORSV) (Inouye dan Gara 1996; Isnawati 2009; Syahierah 2010; Lakani et al. 2010; Kumalawati et al. 2011; Mahfut et al. 2016), Cymbidum mosaic virus (CymMV) (Inouye dan Gara 1996; Menisa 2009; Kumalawati et al. 2011; Lakani 2011), Cucumber mosaic virus (CMV) dan Potyvirus (Lakani 2011). ORSV merupakan virus yang dominan menginfeksi pertanaman anggrek di dunia (Ali et al. 2014; Sudha dan Rani 2015).

Infeksi virus pada tanaman anggrek menyebabkan penurunan vigor tanaman dan kualitas bunga (Koh et al. 2014; Sudha dan Rani 2015). ORSV menyebabkan kerugian secara ekonomi akibat menurunnya kualitas bunga di Florida, Hawai, India, Taiwan, Thailand, Singapura, dan Australia (Zettler et al. 1990; Hu et al. 1993; Wong et al. 1994; Barry et al. 1996; Chang et al. 1996; Sherpa et al. 2006; Khentry et al. 2006; Chang 2008; Ali et al. 2014).

Berdasarkan survei pada 5 kebun raya $(\mathrm{KR})$ di Indonesia, yaitu; KR Bogor (Jawa Barat), KR Cibodas (Jawa Barat), KR Purwodadi (Jawa Timur), KR Balikpapan (Kalimantan Timur), dan KR Enrekang (Makasar) selama tahun 2010-2014 banyak dijumpai anggrek asli dengan gejala terinfeksi virus yang diduga disebabkan oleh ORSV. Penelitian ini bertujuan mendeteksi dan mengidentifikasi ORSV untuk pemutakhiran status kesehatan anggrek asli koleksi kebun raya di Indonesia. Penerapan hasil penelitian ini menjadi salah satu upaya potensial pendukung konsep konservasi anggrek asli di Indonesia melalui upaya perlindungan tanaman.

\section{BAHAN DAN METODE}

\section{Deteksi Protein dengan secara Serologi}

Deteksi serologi untuk menentukan insidensi infeksi virus menggunakan metode DAS-ELISA terhadap 44 total sampel daun anggrek (dari 27 genus) paling representatif berdasarkan pada gejala infeksi dari masingmasing lokasi. ELISA menggunakan antiserum spesifik ORSV sesuai dengan protokol yang direkomendasikan pembuat antiserum (Agdia Inc.). Pewarnaan dengan substrat PNP dibaca menggunakan ELISA-reader (BioTek) pada panjang gelombang $405 \mathrm{~nm}$. Sampel dinyatakan positif apabila nilai absorbansinya mendekati nilai kontrol positif atau paling tidak 2-3 kali nilai absorbansi bufer kontrol (Daryono dan Natsuaki 2009).

\section{Deteksi Asam Nukleat dengan RT-PCR}

Isolasi RNA dilakukan pada sampel positif terinfeksi ORSV secara ELISA, menggunakan total RNA isolation kit dan dilakukan sesuai dengan protokol (SBS Genetech Co., Ltd., China). Amplifikasi RNA dengan RT-PCR dilakukan dengan metode terpisah menggunakan primer spesifik, yaitu ORSV CP-F1(5'ATGTCTTACACTATTACAGACCCG-3') dan ORSV CP-R1 (5'-GGAAGAGGTCCAA GTAAGTCC-3') (Lee dan Chang 2006). 
Tahap reverse transcription (RT) dilakukan dengan first strand cDNA synthesis kit (Thermo Scientific, USA), selanjutnya cDNA yang terbentuk digunakan sebagai cetakan dalam tahap PCR menggunakan GoTaq Green Master Mix (Promega, USA). Reaksi RT dilakukan pada suhu $37{ }^{\circ} \mathrm{C}$ selama 60 menit, dilanjutkan dengan inkubasi pada suhu $96{ }^{\circ} \mathrm{C}$ selama 5 menit dan diakhiri pada suhu $4{ }^{\circ} \mathrm{C}$. Amplifikasi cDNA diawali dengan tahap predenaturasi pada suhu $95^{\circ} \mathrm{C}$ selama 5 menit, dilanjutkan dengan 34 siklus, meliputi denaturasi pada suhu $95^{\circ} \mathrm{C}$ selama 30 detik, aneling pada suhu $50^{\circ} \mathrm{C}$ selama 45 detik, dan ekstensi pada suhu $70^{\circ} \mathrm{C}$ selama 1 menit.

Produk PCR dianalisis menggunakan elektroforesis pada gel agarosa $2 \%$ dalam bufer TBE $1 \times$ menggunakan voltase 50 Volt selama 40 menit. Gel agarosa direndam dalam etidium bromida $\left(10 \mu \mathrm{L} 100 \mathrm{~mL}^{-1}\right)$ selama 30 menit. Pita DNA divisualisasi pada transluminator UV (Bio-Rad Transilluminator 2000) dan didokumentasikan.

\section{Perunutan DNA dan Analisis Filogenetika}

DNA hasil amplifikasi dirunut sikuen nukleotidanya dengan mengirimkan DNA ke FirstBase, Malaysia. Sikuen nukleotida dianalisis dan digabungkan dengan peranti lunak Suite for Sequence Analysis DNASTAR Lasergene DM Version 3.0.25. Analisis penyejajaran sikuen nukleotida ORSV isolat dari Indonesia dilakukan terhadap sikuen yang terdaftar di GenBank menggunakan basic local alignment search tool (BLAST) (www.ncbi.nlm.nih.gov). Seleksi berdasarkan distribusi daerah terpilih diperoleh 4 isolat ORSV terdaftar asal Indonesia dan 10 isolat ORSV asal dari negara lain (Singapura, Cina, India, Jerman, Korea Selatan, Argentina, dan Brazil). Isolat TMV-Yunnan digunakan sebagai pembanding di luar grup (outgrup).

Analisis filogenetika dilakukan dengan menggunakan peranti lunak molecular evolutionary genetics analysis (MEGA) versi 5 Beta) dengan metode neighbor joining (NJ) dan Kimura-2 parameter model untuk estimasi jarak. Nilai bootstrap yang digunakan ialah sebanyak 1000 kali pengulangan.

\section{HASIL}

\section{Deteksi Virus}

Hasil deteksi serologi menunjukkan insidensi infeksi virus sebesar $11.4 \%$. Sebanyak 5 sampel bereaksi positif terhadap antiserum ORSV dengan rerata nilai absorbansi berkisar 1.125-1.152, yaitu 2 sampel berasal dari KR Bogor (KRB2, KRB12), 2 sampel dari KR Purwodadi (KRP18, KRP20), dan 1 sampel dari KR Balikpapan (KRBp5). Dari keseluruhan sampel anggrek yang positif tersebut, 4 di antaranya merupakan Phalaenopsis sp. Sampel daun positif yang terinfeksi ORSV ialah pada Phalaenopsis amboinensis (KRB2), Phalaenopsis amabilis (KRB12), Phalaenopsis amabilis (KRP18), Dendrobium salacence (KRP20), dan Phalaenopsis modesta J. J. Sm. (KRBp5). RT-PCR pada 5 sampel positifORSV menunjukkan adanya fragmen DNA berukuran \pm 474 pb (Gambar 1).

\section{Analisis Sikuen Nukleotida}

Total nukleotida gen $\mathrm{CP}$ isolat ORSVKRB2， KRB12， KRP18， KRP20， dan KRBp5 berukuran 474-480 nukleotida. Analisis BLAST terhadap masing-masing isolat menunjukkan bahwa 5 isolat tersebut memiliki homologi sebesar 99\% dengan isolat ORSV dari negara Asia, Afrika, Amerika, dan Eropa. Hasil analisis 14 isolat ORSV lain menunjukkan homologi sampai dengan 99.8\% dengan isolat ORSV asal kebun raya di Indonesia (Tabel 1).

\section{Pohon Filogenetika Gen CP ORSV}

Hasil penyejajaran sikeun nukleotida menunjukkan adanya mutasi titik berupa substitusi dan insersi pada isolat ORSV di Indonesia. Isolat KRP18 dan KRB12 mengalami kejadian mutasi terbanyak, yaitu transisi dan insersi masing-masing 2 kali sehingga kedua isolat ini terpisah dengan isolat Indonesia lainnya. Efek mutasi yang terjadi mampu menyebabkan perubahan pada triplet kodon penyandi asam amino. Isolat KRP18 menunjukkan perbedaan pada frekuensi asam amino Gly dan Val yang mengalami penurunan masing-masing $4.7 \%$ dan $3.6 \%$ serta peningkatan pada Cys dan 


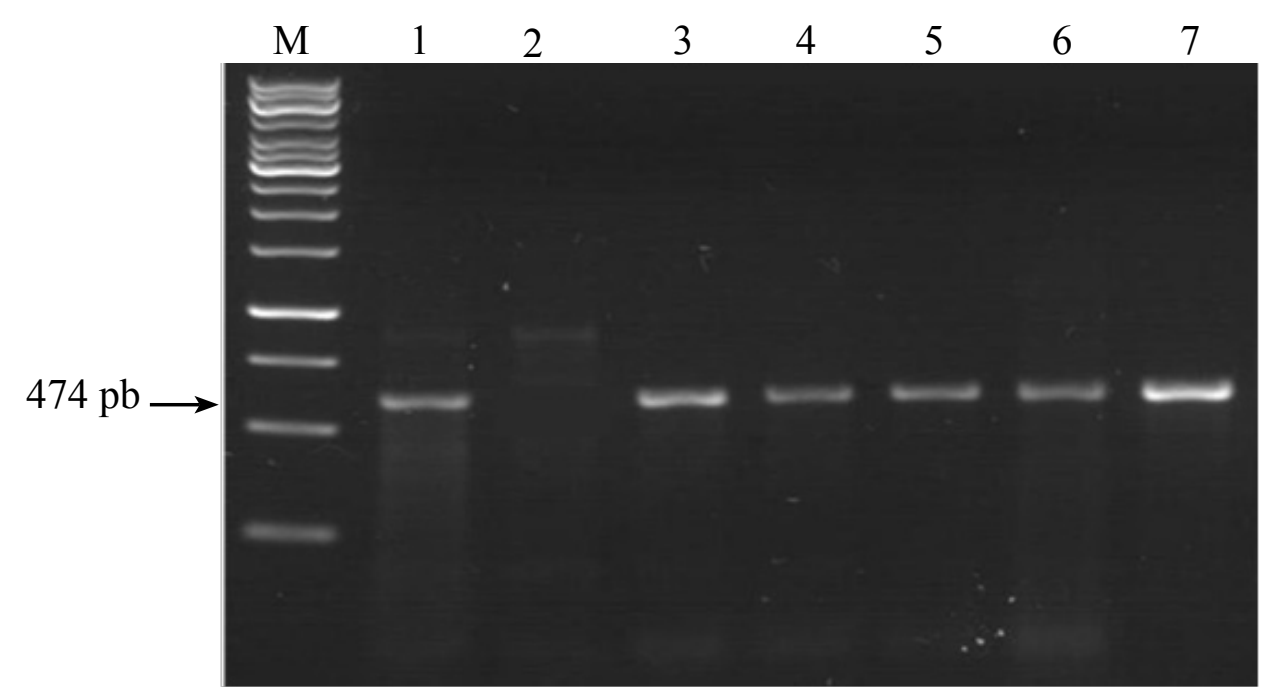

Gambar 1 Visualisasi hasil RT-PCR beberapa isolat ORSV pada gel agarosa 2\%. M, Penanda DNA $1 \mathrm{~kb}$ (Rainbow invitrogen); 1, kontrol positif; 2, kontrol negatif dari tanaman sehat; 3-4, ORSV dari Kebun Raya Bogor (KRB2 dan KRB12); 5-6, ORSV dari Kebun Raya Puwodadi (KRP18 dan KRP20) dan; 7, ORSV dari Kebun Raya Balikpapan (KRBp5).

Asn sebesar $7.1 \%$ dan $11.8 \%$. Berbeda dengan isolat KRB12 yang mengalami peningkatan pada asam amino Gly dan Ala sebesar 7.2\% dan $5.9 \%$, serta penurunan pada Pro $0.8 \%$ dan Tyr 4.7\% (Tabel 2). Pada sikeun nukleotida gen $\mathrm{CP}$ isolat ORSV dalam penelitian ini tidak ditemukan adanya delesi.

Analisis filogenetika menunjukkan bahwa 5 isolat ORSV asal KR di Indonesia memiliki hubungan kekerabatan yang sangat dekat. Hasil analisis pohon filogenetika membagi isolat ORSV menjadi dua kelompok utama, yaitu kelompok isolat Jerman yang terpisah dengan kelompok 18 isolat lainnya. Kelompok ini terbagi menjadi 3 subgrup, yaitu 4 isolat Indonesia yang telah terdaftar di Genbank, 3 isolat kebun raya (Bogor, Balikpapan, dan Purwodadi) dengan 10 isolat dari negara lain, serta 2 isolat KRB2 dan KRP18. Isolat KRB2 dan KRP18 terpisah dari isolat ORSV asal negara lain (Gambar 2). Walaupun keseluruhan isolat membentuk beberapa kelompok, namun kekerabatan antarisolat masih sangat dekat. Hal ini terlihat pada pohon filogenetika tersebut hanya membentuk subgrup.

\section{PEMBAHASAN}

Upaya pemeliharaan anggrek sebaiknya dilakukan secara rutin untuk pemantauan perkembangan dan penyebaran penyakit virus serta tindakan pengendaliannya sedini mungkin. Meskipun insidensinya masih rendah, yaitu $<20 \%$, sama seperti yang dilaporkan oleh Lakani (2011), infeksi ORSV harus mendapat perhatian serius mengingat virus ini paling banyak menginfeksi (Zettler et al. 1990). Di Indonesia, ORSV dilaporkan telah menginfeksi 9 dari total 27 genus anggrek di dunia, yaitu Aranda, Grammatophyllum, Dendrobium, Phalaenopsis, Bulbophylum, Calanthe, Cattleya, dan Oncidium (Inouye dan Gara 1996).

Beberapa mutasi nukleotida yang terjadi menyebabkan 2 isolat ORSV, yaitu KRB12 dan KRP18 terpisah dengan isolat lainnya. Proses terjadinya mutasi nukleotida pada masingmasing isolat didukung oleh kemampuan alami virus untuk beradaptasi dengan lingkungan. Mutasi nukeotida selanjutnya menyebabkan perubahan asam amino yang terbentuk dalam susunan genom virus. Perubahan asam amino tersebut akan mengubah fungsi gen yang disusun sehingga infektivitasnya juga berubah (Lakani et al. 2010).

Gen coat protein (CP) bersifat conserved sehingga memiliki kemampuan mekanisme proffreading seperti umumnya gen nuklear lainnya. Hal ini menyebabkan virus dapat melakukan koreksi dan memperbaiki 
Tabel 1 Tingkat homologi nukleotida gen CP 5 isolat ORSV asal anggrek asli Indonesia dibandingkan dengan isolat dari negara lain

\begin{tabular}{|c|c|c|c|c|c|c|c|c|c|c|c|c|c|c|c|c|c|c|c|c|c|c|}
\hline No & Asal Isolat & No.Aksesi & 1 & 2 & 3 & 4 & 5 & 6 & 7 & 8 & 9 & 10 & 11 & 12 & 13 & 14 & 15 & 16 & 17 & 18 & 19 & 20 \\
\hline 1 & Indonesia-KRB2 & - & 100 & ID & & & & & & & & & & & & & & & & & & \\
\hline 2 & Indonesia-KRB12 & - & 99.5 & 100 & ID & & & & & & & & & & & & & & & & & \\
\hline 3 & Indonesia-KRP18 & - & 97.9 & 98.7 & 100 & ID & & & & & & & & & & & & & & & & \\
\hline 4 & Indonesia-KRP20 & - & 99.4 & 98.9 & 98.3 & 100 & ID & & & & & & & & & & & & & & & \\
\hline 5 & Indonesia-KRBp5 & - & 99.8 & 98.7 & 98.1 & 99.6 & 100 & ID & & & & & & & & & & & & & & \\
\hline 6 & Indonesia-Bogor & AB693989 & 96.6 & 96.6 & 96.0 & 96.6 & 96.6 & 100 & ID & & & & & & & & & & & & & \\
\hline 7 & Indonesia-Cipanas & AB693991 & 98.7 & 99.4 & 98.7 & 99.2 & 98.9 & 97.3 & 100 & ID & & & & & & & & & & & & \\
\hline 8 & $\begin{array}{l}\text { Indonesia-Gunung } \\
\text { Sindur }\end{array}$ & AB693988 & 98.7 & 99.4 & 96.6 & 99.2 & 98.9 & 100 & 95.1 & 100 & ID & & & & & & & & & & & \\
\hline 9 & Indonesia-Jakarta & AB693990 & 96.6 & 97.3 & 98.7 & 97.0 & 96.8 & 97.9 & 97.9 & 96.8 & 100 & ID & & & & & & & & & & \\
\hline 10 & Singapura & U34586 & 98.7 & 99.4 & 98.9 & 99.2 & 98.9 & 99.6 & 99.6 & 97.5 & 97.0 & 100 & ID & & & & & & & & & \\
\hline 11 & India & AJ564563 & 98.9 & 99.6 & 98.5 & 99.4 & 99.2 & 99.8 & 99.8 & 97.7 & 99.8 & 96.8 & 100 & ID & & & & & & & & \\
\hline 12 & Jepang & X55295 & 98.5 & 99.2 & 98.3 & 98.9 & 98.7 & 99.4 & 99.4 & 97.3 & 99.4 & 99.6 & 96.6 & 100 & ID & & & & & & & \\
\hline 13 & Korea Selatan & AJ606107 & 98.3 & 98.9 & 98.3 & 98.7 & 99.5 & 99.2 & 99.2 & 97.0 & 99.2 & 99.4 & 98.9 & 96.6 & 100 & ID & & & & & & \\
\hline 14 & Cina & KP137373 & 98.5 & 99.2 & 98.5 & 98.8 & 98.7 & 99.4 & 99.4 & 97.3 & 99.4 & 99.6 & 99.2 & 98.9 & 97.0 & 100 & ID & & & & & \\
\hline 15 & Taiwan & JN584484 & 98.9 & 99.6 & 98.9 & 99.4 & 99.2 & 99.8 & 99.8 & 97.7 & 99.8 & 100 & 99.6 & 99.4 & 99.6 & 97.0 & 100 & ID & & & & \\
\hline 16 & Amerika & U89894 & 98.9 & 99.6 & 98.9 & 99.4 & 99.2 & 99.8 & 99.8 & 97.7 & 99.8 & 100 & 99.6 & 99.4 & 99.6 & 100 & 94.3 & 100 & ID & & & \\
\hline 17 & Jerman & AJ429091 & 96.2 & 96.8 & 96.2 & 96.6 & 96.4 & 97.0 & 97.0 & 94.9 & 97.0 & 97.3 & 98.8 & 99.6 & 99.8 & 97.3 & 97.3 & 96.7 & 100 & ID & & \\
\hline 18 & Argentina & KT733673 & 97.4 & 98.0 & 97.7 & 98.0 & 97.7 & 98.4 & 98.4 & 95.1 & 98.4 & 98.7 & 98.4 & 98.4 & 98.4 & 98.7 & 98.7 & 94.8 & 84.3 & 100 & ID & \\
\hline 19 & Brazil & AF515606 & 86.0 & 86.5 & 85.9 & 86.2 & 86.2 & 86.8 & 86.8 & 84.7 & 86.8 & 87.0 & 86.6 & 86.8 & 86.6 & 87.0 & 87.0 & 84.3 & 98.4 & 96.6 & 100 & ID \\
\hline 20 & TMV-Yunnan & AAM64218.1 & 68.2 & 68.2 & 67.9 & 67.7 & 67.7 & 67.7 & 67.7 & 66.5 & 67.9 & 67.9 & 66.7 & 68.4 & 68.4 & 67.9 & 97.9 & 67.3 & 67.7 & 61.4 & 100 & 100 \\
\hline
\end{tabular}

Tabel 2 Frekuensi asam amino gen CP ORSV asal anggrek asli Indonesia

\begin{tabular}{|c|c|c|c|c|c|c|c|c|c|c|c|c|c|c|c|c|c|c|c|c|c|}
\hline \multirow{2}{*}{ Asal Isolat } & \multicolumn{21}{|c|}{ Frekuensi Asam Amino (\%) } \\
\hline & Ala & Cys & Asp & Glu & Phe & Gly & His & Ile & Lys & Leu & Met & Asn & Pro & Gln & Arg & Ser & Thr & Val & Trp & Tyr & Total \\
\hline KRB2 & 4.40 & 4.40 & 2.20 & 0.00 & 5.49 & 5.49 & 0.00 & 2.20 & 1.10 & 8.79 & 1.10 & 9.89 & 5.49 & 5.49 & 4.40 & 18.68 & 7.69 & 4.40 & 1.10 & 7.69 & 91 \\
\hline KRB12 & 5.43 & 4.35 & 2.17 & 0.00 & 6.52 & 6.53 & 0.00 & 2.17 & 1.09 & 8.70 & 1.09 & 9.78 & 4.29 & 5.43 & 4.35 & 17.39 & 6.52 & 4.35 & 1.09 & 7.61 & 92 \\
\hline KRP18 & 5.43 & 6.52 & 2.17 & 0.00 & 6.52 & 4.35 & 0.00 & 2.17 & 1.09 & 8.70 & 1.09 & 10.87 & 5.43 & 5.43 & 4.35 & 17.39 & 6.52 & 3.26 & 1.09 & 7.61 & 92 \\
\hline KRP20 & 4.44 & 4.44 & 2.22 & 0.00 & 6.67 & 5.56 & 0.00 & 2.22 & 1.11 & 8.89 & 1.11 & 10.00 & 5.56 & 5.56 & 4.44 & 18.89 & 6.67 & 3.33 & 1.11 & 7.78 & 90 \\
\hline KRBp5 & 4.40 & 4.40 & 2.20 & 0.00 & 5.49 & 5.49 & 0.00 & 2.20 & 1.10 & 8.79 & 1.10 & 9.89 & 5.49 & 5.49 & 4.40 & 18.68 & 7.69 & 4.40 & 1.10 & 7.69 & 91 \\
\hline
\end{tabular}




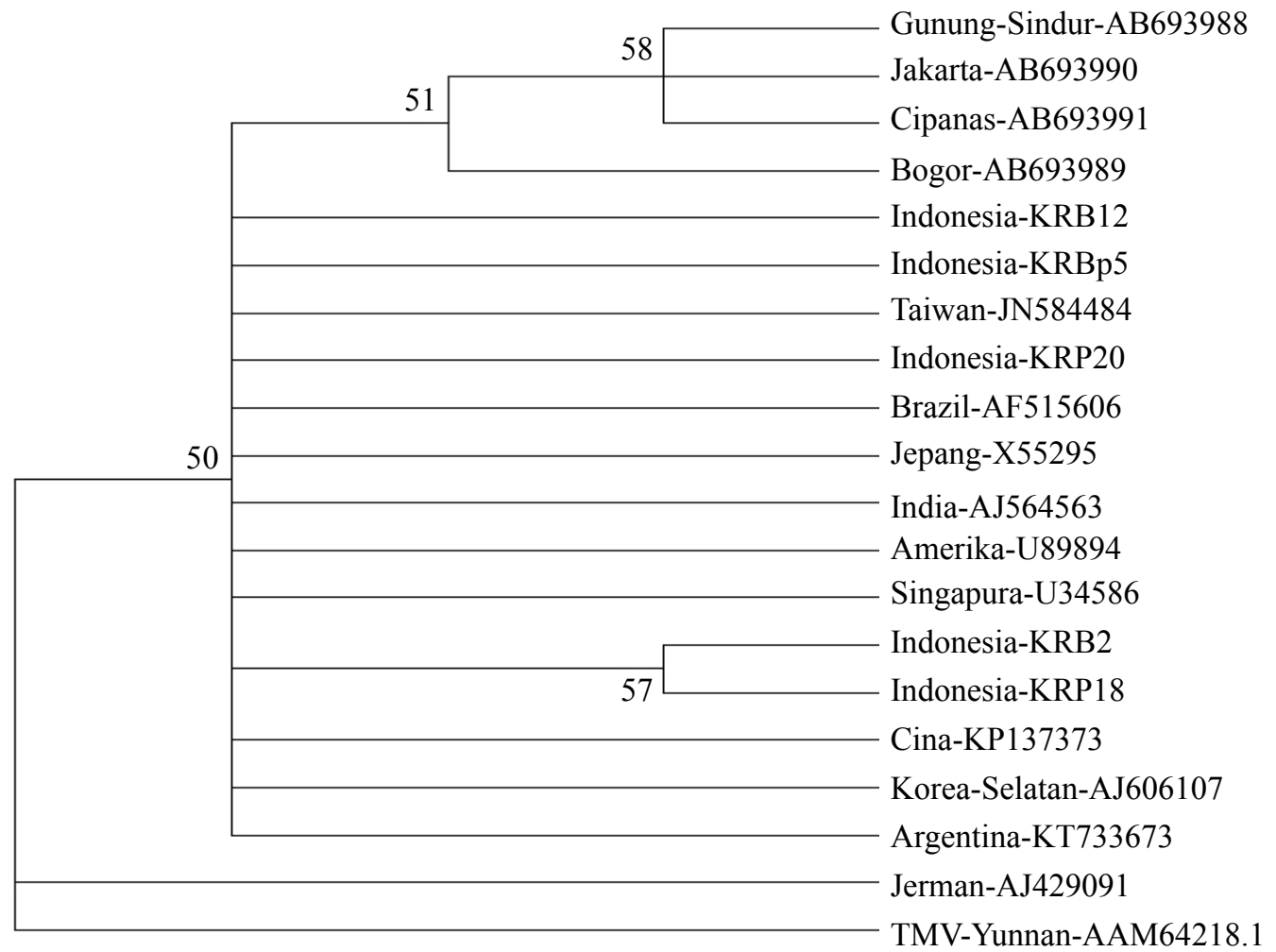

Gambar 2 Pohon filogenetika isolat ORSV berdasarkan sikuen nukleotida gen CP 4 isolat dari Indonesia dibandingkan dengan isolat dari negara lain. TMV-Yunnan digunakan sebagai pembanding luar grup

kesalahan yang terjadi selama proses replikasi genom. Namun dengan ukuran genom virus yang relatif kecil maka adanya sedikit kesalahan akan memberikan pengaruh laju mutasi secara nyata. Laju mutasi akan menghasilkan variasi genetika virus sehingga meningkatkan probabilitas evolusi lebih cepat. Cabang yang cukup panjang pada isolat KRB2 dan KRP18 juga mengindikasikan bahwa virus telah berevolusi, bahkan dapat mengarah terjadinya spesiasi.

ORSV Indonesia diduga berasal dari negara Jerman. BPPP (2005) mencatat Jerman menduduki peringkat 14 sebagai negara yang mengirim benih dan tanaman anggrek ke Indonesia sejak 1997-2001, selain Amerika Serikat, Brazil, India, Singapura, Korea Selatan, Cina, Jepang, Taiwan, dan beberapa negara Asia Barat. Hal ini diperkuat oleh laporan adanya infeksi ORSV di Jerman, Amerika Serikat, Jepang (Lawson 1990), Brazil (Freitas et al. 1999), India (Sherpa et al. 2006), Singapura (Wong et al. 1994). Taiwan (Chang 2008), Korea (Chang et al.
1991), Cina (Rao et al. 2015), dan Taiwan (Zheng et al. 2008). Berdasarkan hal tersebut, cara lain yang efektif untuk melindungi dan mempertahankan status kesehatan anggrek asli di Indonesia ialah dengan membatasi dan mengontrol impor anggrek dari negara lain.

\section{UCAPAN TERIMAKASIH}

Penelitian ini dibiayai oleh Direktorat Riset dan Pengabdian Masyarakat (DRPM), Kementerian Riset Teknologi dan Pendidikan Tinggi Tahun Anggaran 2016, melalui Surat Penugasan Penelitian Hibah Disertasi Doktor Nomor 89/UN26/8/LPPM/2016, Tanggal 13 April 2016.

\section{DAFTAR PUSTAKA}

Ali RN, Dann AL, Cross PA, Wilson CR. 2014. Multiplex RT-PCR detection of three common viruses infecting orchids. Arch Virol. 159(11):3095-3099. DOI: https:// doi.org/10.1007/s00705-014-2161-9. 
Barry K, Hu JS, Kuehnle AR, Sughii N. 1996. Sequence analysis and detection using immunocapture-PCR of Cymbidium mosaic virus and Odontoglossum ringspot virus in Hawaiian orchids. J Phytopathol. 144(4):179-186. DOI: https://doi. org/10.1111/j.1439-0434.1996.tb01511.x.

[BPPP] Balai Penelitian dan Pengembangan Pertanian. 2005. Prospek dan Arah Pengembangan Agribisnis Anggrek. Jakarta (ID): Departemen Pertanian RI.

Chang CA. 2008. Economically important orchid viruses. How to identify and produce clean orchid plantlets. Orchids. 77(9):668-671.

Chang C, Chen CY, Hsu YH, Wu JT, Hu CC, Chang WC, Lin NS. 2005. Transgenic resistance to Cymbidium mosaic virus in Dendrobium expressing the viral capsid protein gene. Transgenic Research. 14:4146. DOI: https://doi.org/10.1007/s11248004-2373-y.

Chang CG, Wong SM, Mahtani PH, Loh CS, Goh CJ, Kao MC, Chung MC, Watanabe Y. 1996. The complete sequence of a Singapore isolate of Odontoglossum ringspot virus and comparison with other Tobamoviruses. Gene. 171(2):155-161. DOI: https://doi.org/10.1016/03781119(96)00046-7.

Chang MU, Chun HH, Baek DH, Chung JD. 1991. Studies on the viruses in orchids in Korea. Dendrobium mosaic virus, Odontoglossum ringspot virus, Orchid fleck virus, and unidentified potyvirus. Korean J Plant Pathol. 7:118-129.

Daryono BS, Natsuaki KT. 2009. Survei virus yang menyerang labu-labuan di Yogyakarta dan Jawa Tengah. J Perlin Tan Indones. 15:83-89.

Freitas AJ, Rezende JAM, Kitajima EW. 1999. Incidence of orchid viruses in the state of São Paulo, Brazil. Fitopatol Bras. 24(2):125-130.

Hu JS, Ferreira S, Wang M, Xu MQ. 1993. Detection of Cymbidium mosaic virus, Odontoglossum ringspot virus, Tomato spotted wilt virus, and Potyviruses infecting orchids in Hawaii. Plant Dis. 77:464-468. DOI: https://doi.org/10.1094/PD-77-0464. Inouye N, Gara, IW. 1996. Detection and identification of viruses of orchid in Indonesia. Bull Res Inst. 4:109-118.

Isnawati L. 2009. Deteksi dan identifikasi Odontoglossum ringspot virus (ORSV) pada tanaman anggrek [skripsi]. Bogor (ID): Institut Pertanian Bogor.

Khentry Y, Paradornuwat A, Tantiwiwat S, Phansiri S, Thaveechai N. 2006. Incidence of Cymbidium mosaic virus and Odontoglossum ringspot virus in Dendrobium spp. in Thailand. Crop Protec. 25(9):926-932. DOI: https://doi. org/10.1016/j.cropro.2005.12.002.

Koh KW, Lu HC, Chan MT. 2014. Virus resistance in orchids. Plant Sci. 228:26-38. DOI: https://doi.org/10.1016/j. plantsci.2014.04.015.

Kumalawati AD, Abdullah S, Setiadi BS, Mahfut. 2011. Study on genetic diversity and convervation of orchids in Wonosadi forest, Gunung Kidul based on molecular analysis. Di dalam: Prosiding International Conference on Biological Science; 2011 Sep 23-24; Yogyakarta (ID): Fakultas Biologi UGM. Hlm. 54.

Lakani I, Suastika G, Mattjik N, Damayanti TA. 2010. Identification and molecular characterization of Odontoglossum ringspot virus (ORSV) from Bogor, Indonesia. Hayati J Biosci. 17(2):101-104. DOI:https://doi.org/10.4308/hjb.17.2.101.

Lakani I. 2011. Identifikasi dan karakterisasi beberapa virus yang menginfeksi tanaman anggrek di Pulau Jawa [disertasi]. Bogor (ID): Institut Pertanian Bogor.

Lawson RH. 1990. Orchid viruses and their control. Di dalam: Handbook on orchid pest and diseases, AM Pridgeon, LL Tillman, editor. Florida (US): American Orchid Society. West Palm Beach. Hlm 66-101.

Lee SC, Chang YC. 2006. Multiplex RTPCR detection of two orchid viruses with an internal control of plant nad5 mRNA. Plant Pathol Bull. 15:187-196. 
Mahfut, Joko T, Daryono BS. 2016. Molecular Characterization of Odontoglossum ringspot virus (ORSV) in Java and Bali, Indonesia. Asian J Plant Pathol. 10(12):9-14. DOI: https://doi.org/10.3923/ ajppaj.2016.9.14.

Menisa F. 2009. Deteksi dan identifikasi Cymbidium mosaic virus (CymMV) pada tanaman anggrek [skripsi]. Bogor (ID): Institut Pertanian Bogor.

Navalinskiene MJ, Raugalas J, Samuitiene M. 2005. Identification of viruses affecting orchids (Cymbidium Sw.). Biologija. 2:29-34.

Rao X, Li Y, Sun J, Li X, Li M, Xiang M. 2015. Genetic diversities of Cymbidium mosaic virus and Odontoglossum ringspot virus isolates based on the coat protein genes from orchids in Guangdong Province, China. J Phytopathol. 163(4):324-329. DOI: https://doi.org/10.1111/jph.12285.

Sherpa AR, Bag TK, Hallan V, Zaidi AA. 2006. Detection of Odontoglossum ringspot virus in orchids from Sikkim, India. Australas Plant Pathol. 35(1):69-71. DOI: https://doi.org/10.1071/ap05094.
Sudha DR, Rani GU. 2015. Detection of Cymbidium mosaic virus (CymMV) on Vanda plants. IJSR. 4(1):374-377.

Syahierah P. 2010. Respon berbagai jenis anggrek (Orchidaceae) terhadap infeksi Cymbidium mosaic virus (CymMV) dan Odontoglossum ringspot virus (ORSV) [skripsi]. Bogor (ID): Institut Pertanian Bogor.

Wong SM, Chng, CG, Lee YH, Tan K, Zettler FW. 1994. Incidence of Cymbidium mosaic and Odontoglossum ringspot viruses and their significance in orchid cultivation in Singapore. Crop Protec. 13(3):235239. DOI: https://doi.org/10.1016/02612194(94)90084-1.

Zettler FW, KoNJ, WislerGC, ElliotMS, WongSM. 1990. Viruses of orchids and their control. Plant Dis. 74:621-626. DOI: https://doi.org/10.1094/PD-74-0621.

Zheng YX, Chen CC, Chen YK, Jan FJ. 2008. Identification and characterization of a potyvirus causing chlorotic spots on Phalaenopsis orchids. Eur J Plant Pathol. 121(1):87-95. DOI: https://doi. org/10.1007/s10658-008-9281-6. 